Situs Jurnal : $\underline{\text { http://ejournal.stiepancasetia.ac.id/index.php/jieb }}$

Jilid 5 Nomor 3 November 2019

Hal 327 - 336

\title{
FAKTOR-FAKTOR YANG MEMPENGARUHI MINAT BERWIRAUSAHA PADA MAHASISWA STIE PANCASETIA BANJARMASIN
}

\section{Muhammad Frive Khoir*, Firda Nosita, dan Asruni}

Abstract: Unemployment is a classic problem in many countries. Entrepreneurship is one of way to reduce unemployment. But, not at all the people who interested in entrepreneurship. The purpose of the study is to determine whether a person's internal and external factors influence entrepreneurial interest. The study was conducted on students of the STIE Pancasetia Banjarmasin. The sample in this study were 230 active students of STIE Pancasetia Banjarmasin. The data was collected by distributing questionnaires online. The results showed that the innovation, profit expectations and the environment had a significant effect on the entrepreneurial interest and the dominant variable is innovation. Entrepreneurship requires a person to be more observant in capturing opportunities amid tight competition. Innovation is one of the important factor for someone to at least enter, survive and compete. Entrepreneurship allows flexibility in determining time, operational and return. Entrepreneurship interest should be developed in order to resolve the unemployment and employment creation.

Keywords: unemployment, entrepreneurship, innovation

Abstrak: Pengangguran masih menjadi masalah klasik di berbagai negara. Berwirausaha adalah salah satu cara untuk mengurangi pengangguran. Namun tidak semua orang tertarik untuk berwirausaha. Tujuan dari penelitian ini adalah untuk mengetahui apakah faktor internal dan eksternal seseorang mempengaruhi minat berwirausaha. Faktor internal dimaksud adalah harga diri, tantangan pribadi, keinginan menjadi bos, inovasi, kepemimpinan, fleksibilitas dan harapan keuntungan sedangkan faktor eksternal adalah lingkungan. Sampel dalam penelitian ini adalah sebanyak 230 orang mahasiswa aktif STIE Pancasetia Banjarmasin. Data dikumpulkan dengan menyebar kuesioner secara daring. Hasil analisis menunjukkan bahwa variabel inovasi, harapan keuntungan dan lingkungan berpengaruh signifikan terhadap minat berwirausaha mahasiswa dan variabel yang dominan adalah inovasi. Berwirausaha menuntut seseorang untuk lebih jeli dalam menangkap peluang ditengah ketatnya persaingan. Inovasi menjadi salah satu faktor penting bagi seseorang untuk setidaknya masuk, bertahan dan bersaing. Berwirausaha memberikan fleksibilitas bagi pelakunya dalam mengatur waktu, operasional sampai keuntungan. Minat berwirausaha perlu ditumbuh kembangkan dalam rangka mengatasi pengangguran dan penciptaan lapangan kerja.

Kata kunci: pengangguran, minat berwirausaha, inovasi

\section{Latar Belakang}

Pembangunan sumber daya manusia perlu dilaksanakan secara menyeluruh, terarah, dan terpadu di berbagai bidang, terutama yang mencakup bidang pendidikan, latihan, serta penyediaan lapangan kerja. Program pengembangan sumber daya manusia pada dasarnya diarahkan agar manusia mampu beradaptasi dengan lingkungan serta mampu aktif mengeksplorasi lingkungan. 
Pengembangan kemampuan intelektual, keterampilan dan kreativitas sangat diperlukan oleh setiap pelaku wirausaha, sehingga mereka mampu mandiri dan selalu berupaya meningkatkan etos kerja yang selanjutnya mereka dapat memperoleh kesempatan kerja atau membuka usaha sendiri (berwirausaha).

Wirausaha merupakan salah satu pendukung yang menentukan maju mundurnya perekonomian, karena bidang wirausaha mempunyai kebebasan untuk berkarya dan mandiri. Wirausaha mampu menciptakan lapangan kerja atau menyerap tenaga kerja. Drucker (dalam Hamali, 2016:11) mengemukakan bahwa kewirausahaan merupakan kemampuan dalam menciptakan sesuatu yang baru dan berbeda. Pengertian ini mengandung maksud bahwa seorang wirausahawan adalah orang yang memiliki kemampuan untuk menciptakan sesuatu yang baru, berbeda dari yang lain, atau mampu menciptakan sesuatu yang berbeda dengan yang sudah sebelumnya.

Pilihan menjadi seorang pengusaha merupakan pilihan yang tepat saat ini sebab dengan berwirausaha berarti menyediakan lapangan kerja bagi diri sendiri dan kemungkinan bagi orang lain. Saat ini para penganggur tak hanya berstatus lulusan SD (Sekolah Dasar) sampai SMA (Sekolah Menengah Atas) saja, tetapi juga banyak sarjana yang menganggur. Badan Pusat Statistik menyebutkan bahwa jumlah angkatan kerja tahun 2018 bertambah 2,95 juta orang dibanding tahun 2017. Peningkatan tersebut berdampak pada peningkatan jumlah pengangguran dan setengah pengangguran yang sangat besar. Tingkat pengangguran terbuka mencapai 5,34 persen dengan jumlah angkatan kerja tahun 2018 sebesar 131,01 juta orang (BPS, 2018).

Saat ini, setiap tahun Indonesia diperkirakan melahirkan 750 ribu sarjana baru. Jumlah itu akan terus bertambah setiap tahun sehingga jumlah angka pencari kerja pun akan semakin meningkat. Fenomena yang terjadi pun adalah penuhnya pengunjung bursa tenaga kerja yang sebagian besar pengunjungnya merupakan kalangan terdidik muda Indonesia yang menganggur. Apabila diasumsikan jumlah sarjana baru tersebut memilih profesi sebagai wirausahawan, dimana dari 750 ribu wirausahawan itu masing-masing dapat menyerap 10 tenaga kerja, maka ada 7,5 juta tenaga kerja yang terserap dan meningkat tiap tahunnya seiring sarjana baru yang meningkat pula (Setiowati, 2013).

Karena begitu besar manfaat serta pengaruh wirausaha bagi sebuah bangsa, maka perlu adanya dorongan dari pemerintah maupun swasta dalam mewujudkan hal tersebut. Salah satunya dengan mendidik dan memberikan pemahaman kepada mahasiswa supaya menjadi calon wirausaha muda terdidik yang diharapkan dapat menampung serta menyelesaikan permasalahan jumlah wirausahawan muda.

Penting untuk menyikapi persaingan dunia bisnis di masa depan yang lebih mengandalkan pada knowledge dan intelectual capital, agar dapat menjadi daya saing bangsa, pengembangan wirausahawan muda perlu diarahkan pada kelompok masyarakat muda terdidik. Mahasiswa adalah calon lulusan perguruan tinggi perlu didorong dan ditumbuhkan minat mereka untuk berwirausaha.

Perguruan Tinggi dapat meningkatkan jumlah wirausahawan dengan mencetak lulusan yang memiliki jiwa wirausaha. Perguruan Tinggi bertanggung jawab dalam mendidik dan memberikan kemampuan wirausaha kepada lulusannya dan memberikan motivasi untuk berani berwirausaha sebagai pilihan karir mereka. Pihak perguruan tinggi perlu menerapkan pola pembelajaran kewirausahaan yang konkrit berdasar masukan empiris untuk membekali mahasiswa dengan pengetahuan agar dapat mendorong semangat mahasiswa untuk berwirausaha (Yohnson dalam Suharti dan Sirine, 2011:125).

Sebagai langkah awal untuk memulai sebuah usaha atau berwirausaha adalah adanya minat pada diri calon wirausahawan. Adanya minat berwirausaha akan menjadikan seseorang lebih giat mencari dan memanfaatkan peluang usaha dengan mengoptimalkan potensi yang 
dimiliki. Minat tidak dibawa sejak lahir tetapi tumbuh dan berkembang sesuai dengan faktorfaktor yang mempengaruhinya.

Penelitian ini menguji apakah faktor-faktor seperti harga diri, tantangan pribadi, keinginan menjadi bos, inovasi, kepemimpinan, fleksibilitas, harapan keuntungan dan lingkungan mempengaruhi minat mahasiswa untuk berwirausaha.

\section{Kajian Literatur}

Wirausaha adalah orang yang mampu menciptakan bisnis baru dan orang yang biasanya langsung berhadapan dengan risiko mampu mengidentifikasikan dalam mencapai keberhasilan. Wirausaha mampu mengidentifikasikan berbagai kesepakatan dan mencurahkan seluruh sumber daya yang ia miliki untuk mengubah kesempatan itu suatu yang menguntungkan (Rahmadi, 2016:155).

Siswandi (2013:5) mendefinisikan minat sebagai suatu kecenderungan yang menyebabkan seseorang berusaha untuk mencari ataupun mencoba aktivitas-aktivitas dalam bidang tertentu. Minat juga diartikan sebagai sikap positif terhadap aspek-aspek lingkungan. Selain itu, minat juga merupakan kecenderungan yang tetap untuk memperhatikan dan menikmati suatu aktivitas disertai dengan rasa senang. Super dan Crites (dalam Ginting dan Yuliawan, 2015:66) menyatakan bahwa seseorang yang mempunyai minat pada obyek tertentu dapat diketahui dari pengungkapan atau ucapan, tindakan atau perbuatan dan dengan menjawab sejumlah pertanyaan.

Faktor-faktor yang mempengaruhi Minat Berwirausaha:

\section{Harga Diri}

Menurut Stuart dan Sundeen (dalam Munith, 2015:94) Harga diri adalah penilaian pribadi terhadap hasil yang dicapai dengan menganalisa seberapa jauh perilaku memenuhi ideal diri. Atau dengan kata lain, harga diri merupakan menggambarkan sejauh mana individu tersebut menilai dirinya sebagai orang yang memiliki kemampuan, keberartian, berharga, dan kompoten. Sedangkan menurut Menurut Clemes, dkk (dalam Pratiwi, 2015:352) harga diri merupakan rasa nilai dari diri yang berasal dari pikiran, perasaan, sensasi, dan pengalaman yang telahdikumpulkan sepanjang hidup. Setiap individu memerlukan harga diri, berapa punusia, jenis kelamin, latar belakang budaya atau arah serta pekerjaan dalam hidupnya.

Menurut pendapat beberapa ahli tersebut, maka dapat disimpulkan bahwa harga diri (self esteem) adalah penilaian individu terhadap kehormatan diri, melalui sikap terhadap dirinya sendiri yang sifatnya implisit dan tidak diverbalisasikan dan menggambarkan sejauh mana individu tersebut menilai dirinya sebagai orang yang memeiliki kemampuan, keberartian, berharga, dan kompeten.

\section{Tantangan Pribadi}

Tantangan atau ancaman merupakan sesuatu yang harus dihadapi oleh suatu perusahaan ataupun organisasi untuk menghadapi berbagai macam faktor lingkungan yang tidak menguntungkan pada suatu perusahaan atau organisasi yang menyebabkan kemunduran. Setidaknya ada 5 tantangan yang harus dihadapi oleh wirausahawan dalam berwirausaha antara lain adalah sebagai berikut : Modal, usia usaha, bakat, ide usaha, serta mencintai usaha yang ditekuni (Mulyadi, 2017:21).

\section{Inovasi}

Inovasi juga sering disebut maknanya dengan penemuan. Inovasi atau reka baru diartikan sebagai proses dan atau hasil pengembangan pemanfaatan dari sebuah pengetahuan, keterampilan (termasuk keterampilan teknologi) dan pengalaman untuk menciptakan atau memperbaiki produk (barang maupun jasa), proses, dan atau sistem yang baru, yang 
memberikan nilai yang berarti secara signifikan terutama ekonomi dan sosial. Menurut Mulyadi (2017:22) ada lima jenis inovasi yang penting dilakukan wirausaha, yaitu:

a. Pengenalan barang baru atau perbaikan barang yang sudah ada.

b. Pengetahuan metode produksi baru.

c. Pembukaan pasar baru, khususnya pasar ekspor atau daerah yang baru.

d. Penciptaan/pengadaan presediaan (supply) bahan mentah atau setengah jadi baru.

e. Penciptaan suatu bentuk organisasi industri

\section{Kepemimpinan}

Kepemimpin berarti kemampuan dan kesiapan yang dimiliki oleh seseorang untuk dapat mempengaruhi, mendorong, mengajak, menuntun, dan mengarahkan orang atau kelompok agar menerima pengaruh tersebut dan selanjutnya berbuat sesuatu yang dapat membantu tercapainya suatu tujuan tertentu yang telah ditetapkan. Menurut Rivai (2012:53) kepemimpinan adalah kemampuan seseorang pemimpin untuk mempengaruhi orang lain dengan cara memancing tumbuhnya perasaan yang positif dalam diri orang-orang yang dipimpinnya untuk mencapai tujuan yang diinginkan.

\section{Fleksibilitas}

Menurut Sutanto (dalam Siswadi, 2013:7) menyebutkan ada beberapa faktor yang memotivasi seseorang untuk menjadi entrepreneur yaitu keinginan merasakan pekerjaan bebas, keberhasilan diri yang dicapai, dan toleransi akan adanya risiko.

Kebebasan dalam bekerja merupakan sebuah model kerja dimana seseorang melakukan pekerjaan sedikit tetapi memperoleh hasil yang besar. Seorang entrepreneur akan memiliki kebebasan waktu bagi dirinya, tidak terikat dengan jam kerja sebagaimana karyawan di dalam perusahaan.

\section{Keuntungan}

Keuntungan atau pendapatan adalah penghasilan yang diperoleh seseorang baik berupa uang maupun barang. Keuntungan juga dapat diartikan sebagai laba yang diperoleh dari usaha yang dibukanya sendiri setelah dikurangi dengan berbagai macam biaya-biaya operasional. Menurut Suhartini (2011:45) Berwiraswasta dapat memberikan pendapatan yang dapat digunakan untuk memenuhi kebutuhan hidupnya. Dalam bisnis, pendapatan adalah jumlah uang yang diterima oleh perusahaan dari aktivitasnya. Kebanyakan dari aktifitas penjualan produk barang maupun jasa kepada pelanggan.

Harapan akan penghasilan yang lebih baik dari hasil usaha yang dibangun untuk memenuhi kebutuhan hidup mereka yang merupakan salah satu faktor yang mempengaruhi apakah seseorang ingin menjadi seorang wirausaha atau tidak. Jika seseorang memiliki keinginan menjadi seorang wirausaha, maka ia akan semakin terdorong untuk menjadi seorang wirausaha. Keinginan untuk memperoleh pendapatan itulah yang dapat menimbulkan minat untuk berwirausaha.

\section{Lingkungan}

Faktor lingkungan mempunyai peran yang signifikan dalam pembentukan seorang wirausahawan. Minat dapat berubah-ubah tergantung dari faktor-faktor yang mempengaruhinya salah satunya adalah faktor lingkungan. Menurut Suhartini (2011:45) menyebutkan ada dua lingkungan yang mempengaruhi minat berwirausaha, yaitu:

a. Lingkungan keluarga

Minat berwirausaha terbentuk ketika lingkungan keluarga memberikan pengaruh positif terhadap minat tersebut, karena sikap dan aktifitas sesama anggota keluarga saling 
mempengaruhi baik secara langsung maupun tidak langsung. Orang tua yang berwirausaha dalam bidang tertentu dapat menimbulkan minat anaknya untuk berwirausaha dalam yang sama pula.

b. Lingkungan Masyarakat

Lingkungan Masyarakat, merupakan lingkungan di luar lingkungan keluarga baik di kawasan tempat tinggalnya maupun dikawasan lain.

\section{Metode Penelitian}

Penelitian ini adalah penelitian korelasional yang menjelaskan hubungan antara faktor yang mempengaruhi minat berwirausaha. Populasi dalam penelitian ini adalah seluruh mahasiswa aktif STIE Pancasetia kampus Banjarmasin, berjumlah 489 mahasiswa.

Ferdinand (2006:226) menyatakan bahwa apabila ukuran sampel terlalu besar maka model menjadi sangat sensitif sehingga sulit untuk mendapatkan goodness of fit yang baik. Maka penentuan jumlah sampel yang representative menurut Hair et al. (1995) adalah 5-10 kali jumlah variabel manifest (indikator) dari keseluruhan variabel laten.

Dalam penelitian ini, jumlah indikator penelitian sebanyak 23 item, sehingga jumlah sampel minimum adalah 10 kali jumlah indikator atau sebanyak $10 \times 23=230$, untuk itu penelitian menggunakan jumlah sampel sebanyak 230 responden, yang diambil secara acak (random). Kuesioner dibagikan secara daring dengan menggunakan google forms.

Definisi operasional masing-masing variabel adalah sebagai berikut:

1. Faktor Yang Mempengaruhi Minat Beriwirausaha (X)

a. Harga Diri (X1), indikatornya berupa keinginan untuk lebih dihargai, memiliki kepercayaan diri, lebih nyaman berbicara dengan orang lain

b. Tantangan Pribadi (X2), indikatornya berupa ingin mencoba hal baru, menyukai sesuatu hal yang membuat lebih maju, melakukan sesuatu hal yang bisa dilakukan orang lain.

c. Inovasi (X3), indikatornya adalah senang dengan hal-hal yang bersifat kreatif, keinginan membuat sesuatu yang berbeda dari yang lain dan senang melakukan percobaan

d. Kepemimpinan (X4), indikatornya adalah suka berbicara dengan orang banyak, ingin menjadi ketua dalam sebuah tim, keinginan untuk lebih menonjol dibandingkan orang lain

e. Fleksibilitas (X5), indikatornya adalah suka dengan pekerjaan yang tidak mengikat waktu, tidak menyukai hal yang bersifat teratur, dan tidak suka terikat sesuatu

f. Harapan Keuntungan (X6), indikatornya adalah berkeinginan bebas menjalankan keuangan, ingin merasakan kekayaan atas usaha sendiri dan keinginan untuk mengembangkan usahanya sendiri

g. Lingkungan (X7), indikatornya antara lain: keluarga mendorong untuk memiliki usaha, orang tua mendukung untuk memiliki usaha dan teman mempengaruhi untuk mempunyai usaha sendiri.

2. Minat Berwirausaha

Adalah keinginan, ketertarikan, serta kesediaan individu untuk bekerja keras dalam memenuhi kebutuhan hidupnya tanpa takut dengan risiko yang akan terjadi (Anggeraeni, 2015:46). Indikator minat berwirausaha antara lain senang terlibat dalam aktifitas wirausaha, keyakinan sukses dengan memiliki usaha sendiri, berwirausaha adalah pekerjaan utama yang ingin dilakukan, senang melakukan percobaan dan keinginan mengembangkan usaha sendiri 
Uji validitas dan reliabilitas dilakukan untuk menguji kesahihan dan kehandalan instrumen yang digunakan. Setelah itu, uji asumsi klasik dilakukan sebelum melakukan uji regresi linear berganda. Model yang diajukan adalah:

$Y=a+b_{1} X_{1}+b_{2} X_{2}+b_{3} X_{3}+b_{4} X_{4}+b_{5} X_{5}+b_{6} X_{6}+b_{7} X_{7}+\varepsilon$

Keterangan

$\mathrm{Y}=$ Minat Berwirausaha

$\mathrm{a}=$ Konstanta

$\mathrm{b}=$ koefisien

$\mathrm{X} 1=$ Harga Diri

$\mathrm{X} 2=$ Tantangan Pribadi

$\mathrm{X} 3=$ Inovasi

$\mathrm{X} 4=$ Kepemimpinan

$\mathrm{X} 5=$ Fleksibilitas

X6=Keuntungan

$\mathrm{X} 7=$ Lingkungan

$\varepsilon=$ Standar error

\section{Hasil Penelitian}

Sebelum melakukan uji regresi, uji validitas dan reliabilitas dilakukan untuk menguji apakah instrumen yang digunakan sudah memenuhi asas kesahihan dan kehandalannya. Dari hasil uji validitas didapatkan bahwa $r$ hitung untuk semua item pernyataan lebih besar dari 0,3 dan memiliki tingkat signifikansi lebih kecil dari 0,05. Sedangkan uji reliabilitas menunjukkan bahwa angka Cronbach's Alpha dari semau variabel lebih dari 0,60 yang berarti bahwa semua variabel memenuhi reliabilitas. Uji asumsi klasik dilakukan dengan uji normalitas, multikolinearitas dan heteroskedastisitas. Hasil uji regresi linear dapat dilihat pada tabel 1.

Tabel 1. Hasil Uji Regresi

\begin{tabular}{lccl}
\hline & B & Std Error & Sig \\
\hline (Constant) & 1.02 & .73 & .166 \\
\hline Harga Diri & .01 & .06 & .878 \\
\hline Inovasi & .01 & .07 & .854 \\
\hline Tantangan Pribadi & .37 & .08 & .000 \\
\hline Kepemimpinan & .05 & .06 & .368 \\
\hline Fleksibilitas & .07 & .05 & .182 \\
\hline Keuntungan & .16 & .07 & .017 \\
\hline Lingkungan & .36 & .07 & .000 \\
\hline
\end{tabular}

Hasil penelitian ini menunjukkan bahwa variabel Harga Diri tidak memiliki pengaruh signifikan terhadap minat berwirausaha mahasiswa STIE Pancasetia Banjarmasin. Hal ini berarti bahwa Harga Diri tidak menimbulkan rasa minat berwirausaha pada mahasiswa STIE Pancasetia Banjarmasin.

Harga diri merupakan penilaian individu terhadap kehormatan dirinya, yang diekspresikan melalui sikap terhadap dirinya. Dalam penelitian ini mahasiswa STIE Pancasetia Banjarmasin pada kenyataannya harga diri dalam kebanggaan memiliki usaha sendiri itu kurang mempengaruhi dalam minat berwirausaha. Adanya perubahan Paradigma yaitu memiliki usaha sendiri tidak lagi menjadi kebanggaan karena menjadi seorang bos tidak lagi diniliai apakah seseorang memiliki usaha sendiri atau tidak. 


\section{Diskusi}

Hasil penelitian ini menunjukkan bahwa variabel Tantangan Pribadi tidak memiliki pengaruh signifikan terhadap minat berwirausaha mahasiswa STIE Pancasetia Banjarmasin. Hal ini berarti bahwa Tantangan Pribadi tidak menimbulkan rasa minat berwirausaha pada mahasiswa STIE Pancasetia Banjarmasin.

Dalam penelitian ini mahasiswa STIE Pancasetia Banjarmasin ternyata ditemukan dalam tantangan pribadi mahasiswa tidak berpengaruh, sebab mahasiswa lebih berhati-hati dalam mengambil keputusan agar tidak menimbulkan risiko terutama pada dunia bisnis yang memiliki tingkat ketidakpastian yang tinggi. Faktor ini sangat berkaitan dengan psikologi seseorang dalam menghadapi sebuah tantangan. Seseorang dapat tertantang dan menghadapinya untuk mencapai tujuan yang diinginkan, namun orang lain mungkin akan merasa nyaman dengan kondisi yang sudah ada dan tidak ingin mengambil risiko meskipun harapan keuntungannya lebih besar.

Variabel inovasi terbukti memiliki pengaruh signifikan dan dominan terhadap minat berwirausaha mahasiswa STIE Pancasetia Banjarmasin. Dengan kata lain, seseorang yang memiliki daya inovasi yang baik, maka minat untuk berwirausaha menjadi lebih tinggi. Inovasi adalah modal utama dalam melakukan bisnis yang semakin kompleks. Bisnis yang mampu berinovasi dengan baik dalam rangka pemenuhan kebutuhan dan keinginan pasar akan cenderung mampu bertahan dan bersaing.

Dengan daya inovasi yang baik, maka sebuah bisnis mampu menggunakan semua keterampilan dan potensi untuk menciptakan nilai tambah barang atau jasa yang kemudian akan menghasilkan keunggulan bagi bisnisnya.

Hasil penelitian ini menunjukkan bahwa variabel Kepemimpinan tidak memiliki pengaruh signifikan terhadap minat berwirausaha mahasiswa STIE Pancasetia Banjarmasin. Jiwa kepemimpinan memang dibuthkan oleh seorang wirausahawan dalam rangka mengelola sumber daya manusia dalam organisasi bisnisnya. Pada kenyataannya, sebuah bisnis dapat tumbuh dalam skala mikro dan kecil yang seringkali tidak membutuhkan banyak sumber daya manusia di dalamnya.

Variabel fleksibilitas juga terbukti tidak memiliki pengaruh signifikan terhadap minat berwirausaha mahasiswa STIE Pancasetia Banjarmasin. Faktor fleksibilitas bukan lagi menjadi daya tarik dari berwirausaha. Memiliki sebuah usaha tidak selalu berarti bahwa pemilik memiliki flksibilitas yang tinggi karena pada kenyataannya sebuah usaha akan bersaing dengan usaha lain dan membutuhkan ketangkasan dan kecepatan dari pemilik agar tetap dapat bersaing.

Hasil penelitian ini menunjukkan bahwa variabel keuntungan memiliki pengaruh signifikan terhadap minat berwirausaha mahasiswa STIE Pancasetia Banjarmasin. Orientasi paling sederhana dari berwirausaha adalah mendapatkan keuntungan (laba). Keuntungan adalah kompensasi yang didapatkan pemilik (atau pengelola) bisnis atas pengorbanan yang dikeluarkan. Dengan berwirausaha, seseorang dapat mengatur keuangan usahanya atau mengatur tingkat keuntungan yang diinginkannya. Dibandingkan dengan menjadi karyawan, berwirausaha memberikan peluang bagi pemilik untuk mendapatkan keuntungan yang tinggi dengan menetapkan keputusan-keputusan yang tepat bagi produk dan penjualannya.

Hasil penelitian ini sejalan dengan penelitian yang dilakukan oleh Suhartini (2011: 58) menyimpulkan bahwa pendapatan berpengaruh terhadap minat berwirausaha. Seseorang akan tertarik untuk menjadi wirausaha karena pendapatan yang diperolehnya jika sukses melebihi karyawan. Seseorang dengan harapan pendapatan yang lebih tinggi daripada bekerja menjadi karyawan menjadi daya tarik untuk menjadi wirausaha.

Variabel lingkungan juga terbukti memiliki pengaruh signifikan terhadap minat berwirausaha mahasiswa STIE Pancasetia Banjarmasin. Faktor lingkungan mempunyai peran 
yang signifikan dalam pembentukan jiwa wirausahawan. Faktor lingkungan adalah faktor eksternal yang dapat mempengaruhi pola pikir seseorang. Seseorang dapat melihat, mengamati, menganalisis dan memutuskan dengan melihat lingkungan sekitarnya. Lingkungan keluarga merupakan lingkungan yang paling dekat dengan seseorang dan menjadi faktor yang penting bagi perkembangan jiwa seseorang. Jiwa berwirausaha dapat tumbuh dengan lingkungan keluarga yang mendukung.

\section{Kesimpulan dan Keterbatasan Penelitian} berikut:

Hasil dari penelitian ini dapat disarikan menjadi beberapa poin kesempulan sebagai

1. Harga Diri, Tantangan Pribadi, Inovasi, Kepemimpinan, Fleksibilitas, Keuntungan, Lingkungan berpengaruh signifikan secara simultan terhadap minat berwirausaha mahasiswa STIE Pancasetia Banjarmasin.

2. Variabel Inovasi, Keuntungan, Lingkungan memiliki pengaruh yang signifikan secara parsial terhadap minat berwirausaha mahasiswa STIE Pancasetia Banjarmasin. Sedangkan variabel Harga Diri, Tantangan Pribadi, Kepemimpinan, Fleksibilitas tidak berpengaruh signifikan secara parsial terhadap minat berwirausaha mahasiswa STIE Pancasetia Banjarmasin.

3. Variabel yang dominan berpengaruh signifikan terhadap Minat Berwirausaha Mahasiswa STIE Pancasetia Banjarmasin yaitu faktor Inovasi. Inovasi memegang peranan penting dalam mengembangkan suatu usaha, dari inovasi menciptakan nilai tambah atas barang atau jasa dalam usaha yang kemudian menciptakan berbagai keunggulan termasuk keunggulan bersaing. Semakin banyak inovasi yang diciptakan, maka akan menimbulkan peluang kesuksesan dalam berwirausaha.

Saran yang diberikan berdasarkan pada hasil penelitian ini meliputi:

1. Bagi objek penelitian diharapkan untuk lebih bisa meningkatkan pengetahuan atau pelatihan yang berkesinambungan kepada mahasiswa agar menumbuhkan minat berwirausaha terutama pada pendekatan Inovasi berupa keterampilan (termasuk keterampilan teknologi) yang memberikan nilai yang berarti secara signifikan terutama ekonomi dan sosial, Keuntungan dan Lingkungan.

2. Bagi Mahasiswa STIE Pancasetia agar bisa mencari informasi yang berkaitan dengan dunia kewirausahaan dan setelah lulus tidak hanya berorientasi untuk mencari kerja, namun juga berusaha untuk menciptakan lapangan pekerjaan agar bisa membantu pemerintah mengurangi angka pengangguran.

3. Bagi penelitian selanjutnya, hendaknya untuk memperluas penelitian sehingga diperoleh informasi yang lebih lengkap mengenai faktor-faktor yang mempengaruhi minat berwirausaha.

\section{DAFTAR PUSTAKA}

Anggraeni, Bety dan Hamanik, 2015, Pengaruh Pengetahuan Kewirausahaan dan Lingkungan Keluarga Terhadap Minat Berwirausaha Siswa Kelas XI SMK Islam Nusantara Comal Kabupaten Pemalang, Vol. 10, No. 1, Hal.42-52.

Badan Pusat Statistik, Jumlah Angkatan Kerja 2018, http:// www.bps.go.id (diakses tanggal 25 Februari 2019)

Badan Pusat Statistik Provinsi Kalimantan selatan, Jumlah Pengangguran (Jiwa) Provinsi Kalimantan Selatan menurut Kabupaten/Kota tahun 2007-2017, http:// kalsel.bps.go.id (diakses tanggal 20 April 2019) 
Evaliana, Yulia. 2015, Pengaruh Efikasi diri dan Lingkungan Keluarga Terhadap Minat Berwirausaha Siswa, Vol. 1, No. 1, Hal.61-70.

Ferdinand, Agusty. 2006. Metode Penelitian Manajemen: Pedoman Penelitian untuk Skripsi, Tesis dan disertai Ilmu Manajemen, Semarang: Badan Penerbit Universitas Diponegoro.

Ghozali, Imam. 2013. Aplikasi Ananlisis Multivariete Dengan Program SPSS. Edisi Ketujuh, Semarang: Badan Penerbit Universitas Diponegoro.

Ginting,M, Yuliawan,E, 2015, Analisis Faktor-Faktor Yang Mempengaruhi Minat Berwirausaha Mahasiswa (studi kasus pada STMIK Mikroskil Medan), Vol. 5, No. 1, Hal.61-69

Gujarati, D.N.,2012., Dasar-dasar Ekonometrika, Terjemahan Mangunsong, R.C., Salemba Empat, buku 2, Edisi 5, Jakarta.

Hamali, Arif, Yusuf, 2016. Pemahaman Strategi Bisnis Dan Kewirausahaan, Prenadamedia Group, Jakarta.

Kementerian Koperasi dan UKM, Perkembangan UMKM tahun2016-2017, http:// www.depkop.go.id (diakses tanggal 05 April 2019)

Mahesa, A dan Rahardja, E, 2012, Analisis Faktor-Faktor Motivasi Yang Mempengaruhi Minat Berwirausaha,Vol. 1, No. 1, Hal.130-137

Mopangga, Herwin, 2014, Faktor Determinan Minat Wirausaha Mahasiswa Fakultas Ekonomi dan Bisnis Universitas Negeri Gorontalo, Vol. 13, No. 1, Hal.78-90.

Mulyadi, H, 2017, Faktor Yang Berpengaruh Terhadap Minat Berwirausaha Mahasiswa Manajemen Bisnis Syariah Fakultas Ekonomi Dan Bisnis Islam IAIN Surakarta, Fakultas Ekonomi Dan Bisnis Islam Institut Agama Islam Negeri Surakarta, Surakarta

Munith, Abdul, 2015, pendidikan keperawatan jiwa, CV Andi Ofset (Penerbit Andi), Yogyakarta.

N. Sora, Analisis SWOT dan Manfaatnya, (diakses tanggal 15 Februari 2019).

Putra, Aditia, Rano, 2012, Faktor-Faktor Penentu Minat Mahasiswa Manajemen Untuk Berwirausaha (Studi Mahasiswa Manajemen FE Universitas Negeri Padang), Vol. 1, No. 1, Hal.1-15.

Praswati, Afliti, Nuryulia, 2014, Analisis Faktor-Faktor Yang Mempengaruh Minat Wirausaha Di Kalangan Mahasiswa Studi Kasus: Fakultas Ekonomi Dan Bisnis Universitas Muhammadiyah Surakarta, Vol. 1, No. 9, Hal.134-142.

Pratiwi,Wahyuni, Eka, 2015, Pengaruh Budaya Jawa Dan Harga Diri Terhadap Asertivitas Pada Remaja Siswa Kelas XDI SMA Negeri 3 Ponorogo, Vol. 3, No. 1, Hal.348-357.

Rahmadi, Afiv Nur,Heryanto Budi, 2016, Analisis Faktor-Faktor Yang Mempengaruhi Minat Berwirausaha Pada Mahasiswa Program Studi Manajemen Fakultas Ekonomi Universitas Kadiri, Vol. 1, No. 2, Hal.153-169.

Rivai, Viethzal dan Deddy Mulyadi, 2012. Kepemimpinan dan Prilaku Organisasi Edisi Ketiga. Jakarta: PT. Rajagrafindo Persada.

Rochayati, U, K,M,S, Sari,A,K, 2015, Pengaruh Faktor Sosiodemografi, Sikap, dan Kontekstual Terhadap Niat Berwirausaha Siswa, Vol. 43, No. 2, Hal.154-163.

Sari, M, 2014, Enterpreneur Terhadap Kinerja UKM Di Kota Medan, Vol. 14, No. 1, Hal.5265.

Santoso, Singgih, 2012, Panduan Lengkap SPSS Versi 20, PT Elex Media Komputindo, Jakarta.

Setiowati, Menumbuhkan Wirausahawan Muda Indonesia dengan Pendidikan Wirausaha Terintegratif, htpp://www.kompasiana.com, (diakses tanggal 25 Februari 2019).

Simamora, Henry, 2014, Manajemen Sumber Daya Manusia, Edisi Ke-3 STIE YKPN, Yogyakarta.

Siregar, Sofyan, 2013, Metode Penelitian Kuantitatif, Kencana, Jakarta. 
Siswandi, Y, 2013, Analisis Faktor Internal, Faktor Eksternal dan Pembelajaran Kewirausahaan Yang Mempengaruhi Minat Mahasiswa Dalam Berwirausaha, Vol. 13, No. 1, Hal.1-17. Sugiyono, 2014. Metode Penelitian Pendidikan Pendekatan Kuantitatif, Kualitatif dan R\&D: Alfabeta, Bandung.

Suharti,.L, Sirine,.H, (2011), Faktor-Faktor yang Berpengaruh Terhadap Niat Kewirausahaan (Entrepreneurial Intention) Studi Terhadap Mahasiswa Universitas Kristen Satya Wacana, Salatiga, Vol.13, No. 2, Hal.124-134

Suhartini, Yati, 2011, Analisis Faktor-Faktor Yang Mempengaruhi Mahasiswa Dalam Berwiraswasta, Vol. 7, No. 1, Hal.38-59.

Sularso, 2008. Metode Penelitian Akuntansi, BPFE, Yogyakarta.

Suryana, 2013, Kewirausahaan Kiat dan Proses Menuju Sukses (Edisi 4), Salemba Empat, Jakarta.

Sritua, 2005. Metode Dalam Penelitian Alfabeta, CV. Bandung. 